\title{
PENGARUH MOTIVASI BELAJAR DAN KECERDASAN SPIRITUAL PADA PRESTASI BELAJAR MAHASISWA AKUNTANSI
}

\author{
Ni Putu Trisna Windika Pratiwi \\ Universitas Hindu Indonesia, email: trisnawindika28@gmail.com
}

\begin{abstract}
Learning achievement plays an important role in measuring how much understanding an individual gets in the learning process that has been followed. The purpose of this study is to provide empirical evidence regarding the effect of learning motivation and spiritual intelligence on the learning achievements of accounting students at the Faculty of Business Economics and Tourism, Hindu Indonesia University. The sample collection method used is a nonprobability sampling technique with a saturated sampling method, so that the number of samples used in this study were 68 students. Research data was collected through questionnaires and analyzed using multiple linear regression analysis techniques. The test results in this study prove that learning motivation and spiritual intelligence have a positive effect on student learning achievement.
\end{abstract}

Keyword: learning motivation, spiritual intelligence, learning achievements

\section{PENDAHULUAN}

Kegiatan belajar mengajar merupakan kegiatan yang sangat penting dilakukan dalam proses pendidikan. Proses pendidikan dapat dimulai dari pra sekolah, sekolah dasar, sekolah menengah, dan perguruan tinggi. Penguruan tinggi merupakan suatu lembaga pendidikan yang menyelenggarakan kegiatan belajar yang dimaksudkan untuk menjalin interaksi antara pengajar dengan peserta didiknya yaitu melalui transfer pengetahuan dan diharapkan nantinya tujuan pendidikan akan tercapai dalam bentuk perubahan perilaku peserta didik (Saputra \& Yuniawan, 2011). Perubahan perilaku yang dimaksud dapat berupa aspek pengetahuan (kognitif), sikap (afektif) maupun aspek psikomotorik. Salah satu perubahan aspek kognitif mahasiswa dapat diukur dengan indeks prestasi yang diperoleh karena indeks prestasi mahasiswa dapat menjadi cerminan seberapa jauh penguasaan akademik mahasiswa yang bersangkutan. 
Prestasi belajar mahasiswa adalah hasil yang dicapai atau diperoleh berupa pengetahuan, keterampilan dan sikap yang berasal dari pengalaman dan latihan yang telah dilalui. Prestasi belajar juga dapat diartikan sebagai cerminan hasil akhir yang dicapai oleh seseorang dalam usaha belajar (Poerwanto, 1986: 28). Prestasi belajar mahasiswa merupakan hasil akhir dari proses belajar mengajar, yaitu nilai akhir mahasiswa di setiap mata kuliah yang ditempuh. Jika nilai akhir mahasiswa itu baik, hal tersebut menandakan bahwa prestasi belajarnya baik dan proses transfer pengetahuan dari pengajar ke peserta didik dapat dikatakan berhasil. Jadi dapat dikatakan bahwa prestasi belajar mahasiswa yang ditunjukkan dengan nilai akhir pada mata kuliah yang ditempuhnya merupakan umpan balik dari berbagai hal seperti kemampuan, keletihan, kekurangan, dan potensi yang dimilikinya (Siagian, 2003: 223).

Salah satu mata kuliah yang harus ditempuh mahasiswa akuntansi adalah mata kuliah Analisis Informasi Keuangan. Analisis informasi keuangan adalah mata kuliah yang termasuk dalam mata kuliah khusus untuk mahasiswa jurusan akuntansi. Mata kuliah ini memaparkan pengetahuan yang berkaitan dengan analisis laporan keuangan. Mahasiswa akuntansi sebagai calon akuntan diharapkan mampu memiliki pengetauhan yang baik pada mata kuliah ini sehingga pada saat turun di dunia kerja dapat bekerja dengan profesional yaitu mampu melakukan analisis terhadap laporan keuangan dengan baik. Untuk mengukur tingkat pemahaman mahasiswa terhadap proses analisis laporan keuangan dapat dilihat dari nilai akhir dari proses belajar yang dilakukan mahasiswa pada mata kuliah tersebut.

Mengingat pentingnya mata kuliah analisis informasi keuangan untuk dipahami mahasiswa, maka perlu diketahui faktor-faktor yang dapat mempengaruhi prestasi belajar mahasiswa. Terdapat dua faktor yang dapat mempengaruhi prestasi belajar yaitu faktor dari dalam diri individu dan faktor dari luar individu. Faktor dalam diri individu yang dapat 
mempengaruhi prestasi belajar mahasiswa antara lain adalah kecerdasan dan motivasi (Purwanto, 2010: 17).

Motivasi belajar memiliki peran penting dalam menentukan prestasi belajar. Pada hakekatnya motivasi adalah dorongan untuk berperilaku guna mencapai tujuan yang telah disusun. Mahasiswa yang dapat dikatakan berhasil dalam belajar adalah mahasiswa yang memiliki dorongan dalam dirinya yang memacunya untuk belajar. Keberhasilan mahasiswa dalam proses belajar sangat tergantung pada motivasi yang diterima mahasiswa tersebut. Oleh karena itu, proses pembelajaran juga harus menjadi suatu hal yang menyenangkan bagi siswa.

Faktor internal lain yang mendukung keberhasilan belajar adalah kecerdasan. Selama ini, jika dikaitkan dengan prestasi belajar maka kecerdasan yang terkait senantiasa dikonotasikan dengan kecerdasan intelektual. Namun anggapan bahwa kecerdasan manusia hanya tertumpu pada dimensi intelektual saja sudah tidak berlaku lagi, sehingga berkembanglah kecerdasan emosional yang meliputi kemampuan untuk mengendalikan diri dan membina hubungan dengan orang lain.

Namun, isu mengenai kecerdasan spiritual mulai muncul, ketika timbul perdebatan antara kecerdasan intelektual dan kecerdasan emosional dalam hal yang berkaitan dengan penentu kesuksesan seseorang (Trihandini, 2005). Hal tersebut dikarenakan, bukan hanya kedua tingkat kecerdasan tersebut yang menentukan kesuksesan seseorang, namun terdapat kecerdasan lain yang tidak kalah pentingnya, yaitu kecerdasan spiritual. Kecerdasan Spiritual memiliki peran sebagai landasan yang diperlukan untuk memfungsikan kecerdasan intelektual dan kecerdasan emosional secara efektif (Agustian, 2001:57). Hal tersebut menegaskan bahwa kecerdasan spiritual memiliki peranan penting dalam penentu kesuksesan mahasiswa dalam meraih prestasi belajar. 
Berdasarkan pemaparan di atas, maka rumusan masalah dalam penelitian ini yaitu bagaimanakah pengaruh motivasi belajar dan kecerdasan spiritual pada prestasi belajar mahasiswa akuntansi Fakultas Ekonomi Bisnis dan Pariwisata Universitas Hindu Indonesia. Sehubungan dengan rumusan masalah, tujuan penelitian adalah untuk memperoleh bukti empiris mengenai pengaruh motivasi belajar dan kecerdasan spiritual pada prestasi belajar mahasiswa akuntansi Fakultas Ekonomi Bisnis dan Pariwisata Universitas Hindu Indonesia. Adapun kegunaan dari penelitian ini adalah untuk memberikan tambahan informasi dan pengetahuan terkait prestasi belajar, motivasi belajar dan kecerdasan spiritual baik untuk penelitian selanjutnya maupun untuk para pengajar.

Goal setting theory merupakan bagian dari teori motivasi yang dikemukakan oleh Locke (1976). Teori ini didasarkan pada konsep seberapa besar pemahaman seseorang pada tujuan yang ingin dicapainya yang akan mempengaruhi perilakunya. Goal setting theory juga menjelaskan bahwa penetapan tujuan memiliki standar tinggi dapat diukur hasilnya sebagai usaha peningkatan prestasi belajar yang diikuti dengan peningkatan kemampuan dan keterampilan kerja yang dimiliki. Apabila seseorang mahasiswa, memiliki dorongan dan keyakinan atas kemampuannya yang dimilikinya untuk mencapai tujuan yang ditetapkan, maka hal tersebut akan mempengaruhi tindakannya untuk memiliki usaha lebih untuk mencapai prestasi belajar yang baik.

Motivasi adalah dorongan individu untuk bertindak sehingga menyebabkan seseorang melakukan suatu perilaku tertentu demi tercapainya tujuan. Motivasi belajar adalah keseluruhan daya penggerak di dalam diri mahasiswa yang menimbulkan keinginan, menjamin kelangsungan dan memberikan arah kedalam kegiatan belajar sehingga diharapkan dapat mencapai prestasi belajar yang diinginkan. Mahasiswa yang memiliki motivasi belajar yang kuat dan tinggi akan memperbesar usaha dan kegiatannya 
untuk mencapai prestasi belajar yang tinggi. Hasil penelitian Basuki (2015) menyatakan bahwa motivasi belajar berpengaruh positif pada prestasi belajar. Sejalan dengan hasil penelitian Mustamin \& Sulasteri (2013), Rafiqah (2014), Riswanto \& Aryani (2017), Asvio et al. (2017) dan Fitriwati (2018) yang menyatakan terdapat pengaruh positif antara hubungan motivasi belajar dengan prestasi belajar. Hipotesis pertama dalam penelitian ini adalah:

$\mathrm{H}_{1} \quad$ : Motivasi belajar berpengaruh positif pada prestasi belajar.

Kecerdasan spiritual merupakan kecerdasan jiwa yang membantu seseorang untuk mengembangkan dirinya secara utuh melalui penciptaan untuk menerapkan norma dan nilai-nilai positif yang ditunjukkan dengan kesadaran untuk menggunakan pengalaman dalam memaknai segala tindakan (Yanti, 2012). Kecerdasan spiritual yang diyakini sebagai kecerdasan yang mampu mengoptimalkan kecerdasan intelektual dan kecerdasan emosional secara efektif dan diyakini merupakan kecerdasan tertinggi yang dimiliki seseorang (Sukidi, 2004:36). Mahasiswa yang memiliki kecerdasan spiritual yang tinggi dicerminkan dari ketekunan yang diimbangi dengan keseimbangan pikiran dan emosi dengan lebih baik sehingga akan dapat memaknai setiap perilakunya berdasarkan nilai dan norma yang positif akan lebih mampu memiliki prestasi belajar yang baik. Hasil penelitian Basuki (2015), Kartikasari (2017) dan Saranya \& Sanggetha (2017) menyatakan kecerdasan spiritual berpengaruh positif pada prestasi belajar. Hipotesis kedua dalam penelitian ini adalah:

$\mathrm{H}_{2} \quad$ : Kecerdasan spiritual berpengaruh positif pada prestasi belajar. 


\section{METODE PENELITIAN}

Lokasi penelitian ini adalah pada Fakultas Ekonomi Bisnis dan Pariwisata Universitas Hindu Indonesia pada tahun 2019. Penelitian ini menggunakan pendekatan asosiatif dalam perumusan masalah. Obyek yang diteliti yaitu terkait kecerdasan spiritual, motivasi belajar dan prestasi belajar. Jenis data yang digunakan adalah data kuantitatif yang diperoleh dari nilai akhir mata kuliah Analisis Informasi Keuangan dan nilai tabulasi hasil kuesioner setra data kualitatif yang diperoleh dari pernyataan dalam kuesioner. Sumber data penelitian bersumber dari data primer. Berikut adalah gambaran desain penelitian yang menggambarkan hubungan variabel independen yaitu motivasi belajar $\left(\mathrm{X}_{1}\right)$ dan kecerdasan spiritual $\left(\mathrm{X}_{2}\right)$ pada variabel dependen prestasi belajar $(\mathrm{Y})$.

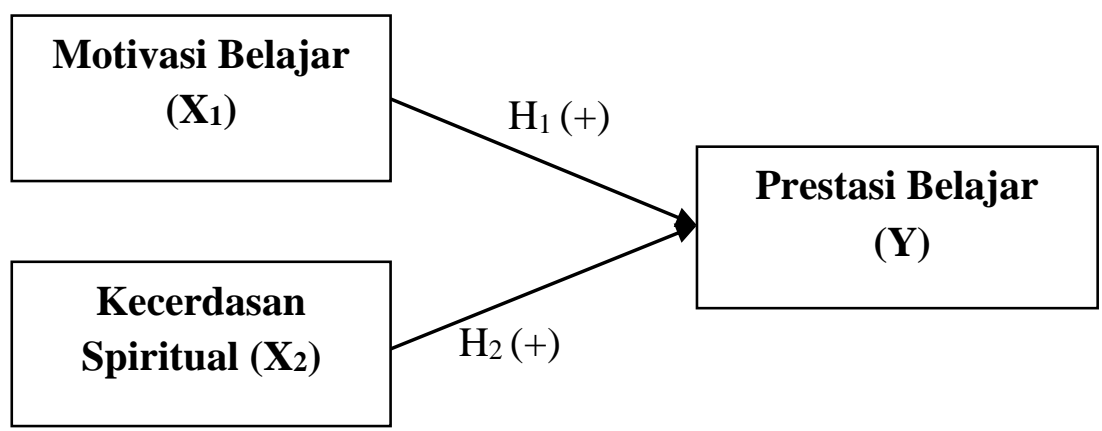

Gambar 1. Desain Penelitian

Populasi penelitian ini adalah seluruh mahasiswa akuntansi semester VI pagi Fakultas Ekonomi Bisnis dan Pariwisata Universitas Hindu Indonesia. Pemilihan sampel penelitian didasarkan pada teknik nonprobability sampling dengan metode sampling jenuh. Jadi, sampel dalam penelitian ini adalah seluruh mahasiswa akuntansi semester VI pagi Fakultas Ekonomi Bisnis dan Pariwisata Universitas Hindu Indonesia yang terdiri dari dua kelas yaitu kelas A dan B dengan jumlah mahasiswa sebanyak 68 orang. Alasan pemilihan sampel tersebut karena mahasiswa akuntansi semester VI pagi Fakultas Ekonomi Bisnis 
dan Pariwisata Universitas Hindu Indonesia telah menempuh mata kuliah Analisis Informasi Keuangan. Metode Pengumpulan data yang digunakan adalah dengan kuesioner penelitian dan rekapitulasi nilai akhir mata kuliah Analisis Informasi Keuangan. Kuesioner penelitian diukur dengan 5 poin skala likert, yang dimana untuk motivasi belajar terdiri atas 15 item pertanyaan yang dirangkum oleh Danar (2013) dan diadopsi dari Herzberg (dalam Robbins dan Judge, 2015) serta kecerdasan spiritual terdiri atas 20 item pertanyaan yang dirangkum oleh Indrajaya (2016) yang diadopsi dari Zohar dan Marshall (2007).

Teknik analisis data yang digunakan adalah analisis regresi linier berganda. Alat bantu statistik berupa SPSS versi 18 yang digunakan untuk menganalisis perhitungan data. Sebelum dilakukan pengujian regresi linier berganda, sebelumnya item pertanyaan dilakukan uji validitas dan reliabilitas. Selanjutnya dilakukan uji asumsi klasik yaitu uji normalitas, uji multikolinieritas dan uji heteroskedastisitas. Model persamaan regresi penelitian ini yaitu: $Y=\alpha+b_{1} X_{1}+b_{2} X_{2}+e$

\section{HASIL DAN PEMBAHASAN}

Kuesioner yang disebar dalam penelitian ini adalah 68 kuesioner. Kuesioner yang kembali sebanyak 68 kuesioner. Kuesioner yang layak untuk dianalisis adalah sebanyak 68 kuesioner (dengan response rate sebesar 100\%). Berdasarkan Tabel 1 dijelaskan tingkat pengembalian kuesioner yaitu sebagai berikut:

\section{Tabel 1. Tingkat Pengembalian Kuesioner}

\begin{tabular}{l|c}
\hline \multicolumn{1}{c|}{ Keterangan } & Jumlah \\
\hline Kuesioner yang disebar & 68 \\
Kuesioner yang kembali & $\mathbf{6 8}$ \\
Kuesioner yang tidak lengkap & $(0)$ \\
Kuesioner yang layak dianalisis & $\mathbf{6 8}$ \\
\hline
\end{tabular}


Tingkat Pengembalian/Response Rate

Kuesioner yang dikembalikan Kuesioner yang dikirim $\times 100 \%$

$100 \%$

Sumber: Data Diolah (2019)

Statistik deskriptif dalam penelitian ini disajikan untuk memberikan informasi tentang karakteristik variabel penelitian, antara lain nilai minimum, nilai maksimum, mean dan deviasi standar. Hasil analisis statistik deskriptif dari penelitian ini disajikan pada Tabel 2 yaitu sebagai berikut:

Tabel 2. Statistik Deskriptif

\begin{tabular}{lccccc}
\hline \multicolumn{1}{c}{ Variabel Penelitian } & N & $\begin{array}{c}\text { Nilai } \\
\text { Minimum }\end{array}$ & $\begin{array}{c}\text { Nilai } \\
\text { Maksimum }\end{array}$ & Mean & Deviasi Standar \\
\hline Motivasi Belajar & 68 & 54 & 75 & 64,48 & 5,63 \\
Kecerdasan Spiritual & 68 & 62 & 95 & 83,08 & 6,77 \\
Prestasi Belajar & 68 & 87 & 97 & 92,45 & 2,20 \\
Valid N (listwise) & 68 & & & & \\
\hline
\end{tabular}

Sumber: Data Diolah (2019)

Hasil uji instrumen yang terdiri dari uji validitas dan reliabilitas. Untuk hasil uji validitas instrumen dari setiap item pernyataan dari masing-masing variabel independen penelitian yaitu motivasi belajar dan kecerdasan spiritual, diketahui memiliki nilai koefisien korelasi lebih dari 0,30 sehingga, seluruh item pernyataan pada kuesioner penelitian dapat dinyatakan valid. Untuk hasil uji reliabilitas masing-masing variabel independen penelitian yaitu motivasi belajar dan kecerdasan spiritual memiliki nilai cronbach's alpha lebih dari 0,70 sehingga variabel penelitian dapat dinyatakan reliabel.

Uji asumsi klasik dilakukan sebelum pengujian hipotesis, pengujian ini perlu diterapkan karena suatu model regresi akan dapat dianalisis dengan baik apabila memenuhi persyaratan asumsi klasik (Ghozhali, 2006). Uji asumsi klasik dalam penelitian ini terdiri 
atas uji normalitas, uji multikolinieritas dan uji heteroskedastisitas. Hasil uji normalitas memperoleh nilai signifikansi Kolmogorov-Smirnov sebesar 0,922 lebih dari 0,05. Artinya data dalam model regresi telah terdistribusi normal. Hasil uji normalitas dari penelitian ini disajikan pada Tabel 3 yaitu sebagai berikut:

\section{Tabel 3. Hasil Uji Normalitas}

\begin{tabular}{lc}
\hline \multicolumn{1}{c}{ Uraian } & Unstandardized Residual \\
\hline $\mathrm{N}$ & 68 \\
Kolmogorov-Smirnov $(\mathrm{Z})$ & 0,550 \\
Asymp. Sig (2-tailed) & 0,922 \\
\hline
\end{tabular}

Sumber: Data Diolah (2019)

Hasil pengujian multikoliniearitas menunjukkan seluruh variabel independen mempunyai nilai tolerance lebih dari 0,1 dan nilai variance inflation factor kurang dari 10 sehingga menunjukkan tidak ada indikasi terjadi multikolinearitas. Hasil uji multikolinieritas dari penelitian ini disajikan pada Tabel 4 yaitu sebagai berikut:

\section{Tabel 4. Hasil Uji Multikolinieritas}

\begin{tabular}{lcc}
\hline \multicolumn{1}{c}{ Variabel Penelitian } & \multicolumn{2}{c}{ Collinearity Statistic } \\
& Tolerance & VIF \\
\hline Motivasi Belajar & 0,680 & 1,470 \\
Kecerdasan Spiritual & 0,680 & 1,470 \\
\hline
\end{tabular}

Sumber: Data Diolah (2019)

Hasil uji heteroskedastisitas menggunakan metode glejser menunjukkan bahwa hasil uji heteroskedastisitas signifikan dari semua variabel independen memiliki nilai lebih dari 0,05 . Sehingga model ini tidak mengandung gejala heteroskedastisitas. Hasil uji heteroskedastisitas dari penelitian ini disajikan pada Tabel 5 yaitu sebagai berikut: 
Tabel 5. Hasil Uji Heteroskedastisitas

\begin{tabular}{lcc}
\hline \multicolumn{1}{c}{ Variabel Penelitian } & t hitung & Sig. \\
\hline Motivasi Belajar & 2,936 & 0,185 \\
Kecerdasan Spiritual & $-1,630$ & 0,108 \\
\hline
\end{tabular}

Sumber: Data Diolah (2019)

Penelitian ini menggunakan analisis regresi linier berganda untuk melakukan pengujian terhadap hipotesis penelitian. Penelitian ini menggunakan dua variabel independen, yaitu motivasi belajar dan kecerdasan spiritual serta satu variabel dependen yaitu prestasi belajar. Berikut adalah hasil uji analisis regresi linier berganda dalam penelitian ini. Sebelum melakukan pengujian terhadap hipotesis penelitian, sebelumnya dilakukan pengujian variabel independen pada variabel dependen secara simultan (Uji F) dan Koefisien Determinasi.

Hasil uji $\mathrm{F}$ yang diperoleh menyatakan bahwa nilai koefisien $\mathrm{F}$ hitung sebesar 12,804 dengan signifikansi sebesar 0,000 kurang dari 0,05. Hal ini berarti bahwa model penelitian ini layak untuk dianalisis lebih lanjut. Hasil uji heteroskedastisitas dari penelitian ini disajikan pada Tabel 6 yaitu sebagai berikut:

\section{Tabel 6. Hasil Uji F}

\begin{tabular}{lccccc}
\hline \multicolumn{1}{c}{ Model } & $\begin{array}{c}\text { Sum of } \\
\text { Squares }\end{array}$ & Df & $\begin{array}{c}\text { Mean } \\
\text { Square }\end{array}$ & F & Sig. \\
\hline Regression & 91,817 & 2 & 45,909 & 12,804 & 0,000 \\
Residual & 233,051 & 65 & 3,585 & & \\
Total & 324,868 & 67 & & & \\
\hline
\end{tabular}

Sumber: Data Diolah (2019)

Pengujian koefisien determinasi dapat dilihat dari nilai adjusted $\mathrm{R}$ square sebesar 0,283 yang berarti bahwa $28,30 \%$ variasi naik turunnya perubahan prestasi belajar 
dipengaruhi oleh variabel dependen motivasi belajar dan kecerdasan spiritual, sedangkan $71,70 \%$ sisanya dipengaruhi oleh variabel lain yang tidak dijelaskan dalam model penelitian ini.

Tabel 7. Hasil Koefisien Determinasi $\left(\mathbf{R}^{2}\right)$

\begin{tabular}{ccccc}
\hline Model & R & R Square & $\begin{array}{c}\text { Adjusted } \mathbf{R} \\
\text { Square }\end{array}$ & $\begin{array}{c}\text { Std. Error of the } \\
\text { Estimate }\end{array}$ \\
\hline 1 & 0,532 & 0,283 & 0,261 & 1,89351
\end{tabular}

Sumber: Data Diolah (2019)

Tabel 8. Hasil Uji Regresi Linier Berganda

\begin{tabular}{lccccc}
\hline \multirow{1}{*}{ Model } & \multicolumn{2}{c}{ Unstandardized } & \multicolumn{2}{c}{ Standardized } & \\
& \multicolumn{2}{c}{ Coefficient } & Coefficient & t & Sig. \\
& B & Std. & Beta & & \\
& & Error & & & \\
\hline Konstanta & 76,742 & 3,114 & & 24,647 & 0,000 \\
Motivasi Belajar & 0,101 & 0,050 & 0,260 & 2,041 & 0,045 \\
Kecerdasan Spiritual & 0,110 & 0,041 & 0,340 & 2,666 & 0,010 \\
\hline
\end{tabular}

Sumber: Data Diolah (2019)

Berdasarkan Tabel 8 dapat dilihat hasil uji regresi linier berganda dalam penelitian ini, sehingga dapat disusun persamaan regresi sebagai berikut:

$$
\mathrm{Y}=76,742+0,101 \mathrm{X}_{1}+0,110 \mathrm{X}_{2}+\mathrm{e}
$$

\section{Pengujian Hipotesis}

\section{Pengaruh Motivasi Belajar pada Prestasi Belajar}

Berdasarkan Tabel 8 hasil penelitian menunjukkan bahwa koefisien beta $\left(\beta_{1}\right)$ sebesar 0,101 dengan tingkat signifikansi sebesar 0,045 kurang dari 0,05. Hal tersebut 
berarti bahwa motivasi belajar berpengaruh positif pada prestasi belajar mahasiswa akuntansi Fakultas Ekonomi Bisnis dan Pariwisata Universitas Hindu Indonesia, sehingga $\mathrm{H}_{1}$ diterima. Semakin tinggi motivasi belajar yang dimiliki oleh seorang mahasiswa maka prestasi belajar mahasiswa tersebut juga akan semakin baik. Mahasiswa yang termotivasi untuk memperoleh nilai yang baik akan berusaha untuk berusaha untuk mencapai prestasi yang diinginkan. Hasil penelitian ini didukung oleh hasil penelitian yang diperoleh Basuki (2015), Mustamin \& Sulasteri (2013), Rafiqah (2014), Asvio et al. (2017) dan Fitriwati (2018).

\section{Pengaruh Kecerdasan Spiritual pada Prestasi Belajar}

Berdasarkan Tabel 8 hasil penelitian menunjukkan bahwa koefisien beta $\left(\beta_{2}\right)$ sebesar 0,110 dengan tingkat signifikansi sebesar 0,010 kurang dari 0,05. Hal tersebut berarti bahwa kecerdasan spiritual berpengaruh positif pada prestasi belajar mahasiswa akuntansi Fakultas Ekonomi Bisnis dan Pariwisata Universitas Hindu Indonesia, sehingga $\mathrm{H}_{2}$ diterima. Mahasiswa yang memiliki kecerdasan spiritual yang tinggi maka akan memiliki prestasi belajar yang baik pula. Mahasiswa yang memiliki kecerdasan spiritual akan lebih mampu untuk mengoptimalkan kecerdasan intelektual dan kecerdasan emosional yang dimilikinya sehingga memiliki ketekunan dan siap dalam proses menghadapi dan memecahkan masalah yang dialaminya serta memiliki pengendalian diri dan emosi untuk dapat membina hubungan yang baik dengan orang lain. Hasil penelitian ini didukung oleh hasil penelitian yang dilakukan oleh Basuki (2015), Kartikasari (2017) dan Saranya \& Sanggetha (2017).

\section{SIMPULAN DAN SARAN}

Berdasarkan hasil analisis dan pembahasan hasil penelitian, maka dapat disimpulkan bahwa motivasi belajar dan kecerdasan spiritual berpengaruh positif pada 
prestasi belajar mahasiswa akuntansi Fakultas Ekonomi Bisnis dan Pariwisata Universitas Hindu Indonesia. Tingkat motivasi belajar yang tinggi dan kecerdasan spiritual yang dimiliki mahasiswa akan berdampak pada peningkatan prestasi belajar yang dapat diraih oleh mahasiswa tersebut.

Saran yang dapat diberikan berdasarkan dari hasil penelitian yang diperoleh, yaitu untuk penelitian selanjutnya, dilihat dari nilai adjusted $\mathrm{R}$ square sebesar 0,283, maka diketahui terdapat faktor lain yang dapat mempengaruhi prestasi belajar, sehingga untuk peneliti selanjutnya dapat menambahkan variabel lain yang dapat mempengaruhi prestasi belajar, seperti minat belajar, budaya organisasi, dan metode pembelajaran.

\section{DAFTAR PUSTAKA}

Agustian, Ary Ginanjar. 2001. ESQ (Emotional Spiritual Quotient). Jakarta: Arga.

Asvio, Nova, Arpinus and Suharmon. 2017. The Influence of Learning Motivation and Learning Environment on Undergraduate Students' Learning Achievement of Management of Islamic Education, Study Program of Iain Batusangkar In 2016. Noble International Journal of Social Sciences Research. Vol. 2, No. 2.

Basuki, Kasih Haryo. 2015. Pengaruh Kecerdasan Spiritual dan Motivasi Belajar Terhadap Prestasi Belajar Matematika. Jurnal Formatif. Vol. 5(2), hal. 120-133. ISSN: 2088$351 X$.

Danar, Vreedy Frans. 2013. Hubungan Minat Belajar Siswa dan Motivasi Belajar Siswa Dengan Prestasi Belajar Siswa Kelas X Kompetensi Keahlian Teknik Audio SMK Ma'arif. Skripsi. Fakultas Teknik Universitas Negeri Yogyakarta.

Fitriwati, Dewi Ginaib. 2018. The Effect of Motivation on the Learning Achievement. Indonesian Journal of Integrated English Language Teacing. Vol. 4 No.1.

Ghozali, Imam. 2006. Aplikasi Analisis Multivariate dengan Program SPSS. Semarang: Badan Penerbit Universitas Diponegoro.

Indrajaya, A. A. Ngurah. 2016. Pengaruh IQ, EQ, SQ dan Tekanan Anggaran Waktu Audit Pada Perilaku Underreporting of Time. Tesis. Universitas Udayana.

Kartikasari, Dewy. 2017. Pengaruh Kecerdasan Spiritual dan Motivasi Belajar Terhadap Hasil Belajar Kelas X Mata Pelajaran Sosiologi. Skripsi. Faskultas Ilmu Tarbiyah dan Keguruan Universitas Islam Negeri Maulana Malik Ibrahim. 
Locke, E.A, 1976, The Nature and Causes of Job Satisfaction, NewYork: John Wiley and Sons.

Mustamin, Hasmiah dan Sri Sulasteri. 2013. Faktor-Faktor Yang Mempengaruhi Prestasi Belajar Mahasiswa Jurusan Pendidikan Matematika Fakultas Tarbiyah Dan Keguruan Uin Alauddin Makassar. Jurnal Matematika dan Pembelajaran. Vol. 1 No. 1.

Purwanto, Ngalim. 1986. Prinsip-Prinsip dan Teknik Evaluasi Pengajaran. Bandung: Rosdakarya

Purwanto, Ngalim. 2010. Psikologi Pendidikan. Bandung : Remaja Rosdakarya.

Rafiqah, Mar'atur. 2014. Pengaruh Motivasi Belajar Terhadap Prestasi Belajar. Jurnal FKIP. Universitas Lampung

Riswanto, Ari dan Sri Aryani. 2017. Learning Motivation And Student Achievement: Description Analysis And Relationships Both. The International Journal of Counseling and Education. Vol 2 No. 1.

Saputra, Vicky Dwi dan Yuniawan, A. 2011. Analisis Kepribadian Dosen yang Berpengaruh terhadap Prestasi Belajar (Studi pada Mahasiswa Fakultas Ekonomi Universitas Diponegoro). Skripsi. Fakultas Ekonomi Universitas Diponegoro Semarang.

Saranya, R. and T. Sangeetha. 2017. A Study Of Spiritual Intelligence In Relation To Achievement In Science Among Secondary School Students In Coimbatore Educational District. International Journal of Research- Granthaalayah. Vol 5.

Siagian, Sondang P. 2003. Manajemen Sumber Daya Manusia. Jakarta : Bumi Aksara

Sukidi. 2004. Kecerdasan Spiritual. Jakarta: PT. Gramedia Pustaka Utama.

Trihandini, R. A. Fabiola Meirnayati. 2005. Analisis Pengaruh Kecerdasan Intelektual, Kecerdasan Emosi dan Kecerdasan Spiritual Terhadap Kinerja Karyawan. Tesis. Semarang: Universitas Dipenogoro.

Yanti, Imelda. 2012. Pengaruh Kecerdasan Spiritual terhadap Kinerja Auditor Pada Kantor Akuntan Publik (Studi Empiris pada Provinsi Riau dan Sumatra Barat). Jurnal Akuntansi. Universitas Riau. Pekanbaru.

Zohar, D dan I. Marshall. 2007. SQ: Kecerdasan Spiritual. (Rahmani Astusti, Ahmad Nadjib Burhani, Ahmad Baiquini. Terjemaham). Bandung: PT Mizan Pustaka. 